\title{
Sekwencje depozycyjne w utworach miocenu autochtonicznego w rejonie Brzeska
}

\begin{abstract}
Stratygrafia sekwencji jest multikompontentowym narzędziem służącym do odwzorowywania architektury depozycyjnej, środowisk sedymentacji, litofacji i ich przestrzennego rozmieszczenia. Podstawową jednostką wyróżnianą w tej metodzie jest sekwencja depozycyjna, definiowana jako genetyczne następstwo powiązanych ze sobą warstw, ograniczone w spągu i stropie poprzez subaeralne niezgodności lub ich korelatywne zgodności (granic sekwencji), które są wynikiem zmian względnego poziomu morza, towarzyszących wypełnianiu basenów sedymentacyjnych. Przedstawiona próba interpretacji materiałów sejsmicznych, obejmująca mioceńską sukcesję nadewaporatową w rejonie Brzeska, na podstawie założeń tej metodyki i przy wykorzystaniu pomiarów geofizyki otworowej i ich wzajemnym dowiązaniu, pozwoliła na zidentyfikowanie 11 granic sekwencji (SB) i 9 powierzchni maksimum zalewu (MFS). W obrębie tych sekwencji, w zapisie sejsmicznym, karotażowym i w oparciu o dane literaturowe, zinterpretowano elementy architektury depozycyjnej zdominowane litofacją piaskowcową, deponowaną głównie w trakcie niskiego stanu WMP. Zostały one zinterpretowane jako nasypy przyujściowe/bary piaszczyste oraz fragmenty wciętych dolin w strefie szelfu.
\end{abstract}

Słowa kluczowe: zapadlisko przedkarpackie, miocen autochtoniczny, stratygrafia sekwencji, elementy szelfowej architektury depozycyjnej.

\section{Depositional sequences of autochthonous Miocene strata in the Brzesko area}

Sequence stratigraphy is a multi-component tool for mapping the depositional architecture, sedimentary environments, lithofacies and their spatial distribution. The basic unit of distinction in this method is a depositional sequence, defined as a genetic consequence of interconnected layers, limited in the bottom and top by unconformities or corelative conformities (sequences borders). They are the result of changes in relative sea level that accompanies filling sedimentary basins. The study area included upper Badenian-lower Sarmatian (Miocen) strata in the region of Brzesko. Methodology used in conjunction with well logs and geological data allowed identification in the seismic 11 sequence boundaries (SB) and 9 of the maximum flooding surface (MFS). Within the sequence the elements of depositional architecture were interpreted. They were dominated by sandstone facies that had been deposited mainly during the low state of relative sea level.

Key words: Carpathian Foreland Basin, Miocene, sequence stratigraphy, shelf-margin delta.

\section{Wstęp}

Utwory nadewaporatowe miocenu autochtonicznego w rejonie Kraków - Brzesko (rysunek 1), dzięki odkryciom złóż gazu ziemnego oraz zaobserwowanym objawom w trakcie wiercenia w całym tym rejonie, były przedmiotem wielu prac poszukiwawczych i badawczych. Szczegółowe prace analityczne, wiążące nowoczesne metody badawcze wykorzystujące metodę stratygrafii sekwencyjnej czy sejsmostratygrafii, wykonali wcześniej Jędrzejowska-Zwinczak i Połtowicz [5], Porębski i in. [15], Porębski i Steel [16] oraz Krzywiec [6-8]. Prace te miały na celu uszczegółowienie zakre- su wiedzy na temat tych utworów i warunków ich sedymentacji oraz dystrybucji facji zbiornikowych pod kątem przyszłych prac poszukiwawczych. W wyniku nowych odkryć i uzyskiwania coraz nowszej wiedzy na temat utworów mioceńskich stwierdzono, że skałami zbiornikowymi dla gazu są nie tylko piaskowce, ale też mułowce i mułowce ilaste w formie cienkowarstwowych utworów o charakterze heterolitów. Czynnikiem zaś kontrolującym występowanie złóż gazu ziemnego w tych skałach nie są tylko warunki strukturalne, ale i zmiany facjalne, które określają zasięg hory- 
zontów gazonośnych. Mimo że zbiór danych sejsmicznych, jak i otworowych jest bardzo duży, to stan rozpoznania litofacjalnego jest dość wycinkowy z powodu przypadkowego rdzeniowania sukcesji nadewaporatowej.

Założeniem pracy było połączenie dotychczasowej wiedzy o obszarze i wykorzystanie danych sejsmicznych 3D w celu ponownego przeanalizowania rejonu Brzeska i identyfika- cji elementów architektury depozycyjnej, z którymi mogą się wiązać nagromadzenia gazu ziemnego. Do rozwiązania tego zagadnienia wykorzystano dostępny zestaw informacji geologicznej i geofizycznej oraz metodykę łączącą stratygrafię sekwencji i stratygrafię sejsmiczną. Wynikiem tej pracy jest interpretacja regionalnej sejsmicznej linii korelacyjnej o przebiegu S-N o łącznej długości $25 \mathrm{~km}$.

\section{Obszar badań i zarys budowy geologicznej}

Analizowany obszar zapadliska przedkarpackiego zlokalizowany jest w południowo-zachodniej części przedgórza Karpat, w rejonie Brzeska (rysunek 1). Obejmuje on zarówno autochtoniczne, jak i allochtoniczne utwory miocenu, związane z południową, tektoniczną granicą zapadliska, wyznaczoną przez czoło Karpat zewnętrznych i jednostkę zgłobicką, będącą strefą deformacji tektonicznych.

W ujęciu stratygraficznym najstarszymi utworami miocenu w tej części zapadliska przedkarpackiego są dolnobadeńskie utwory formacji skawińskiej, które nie były przedmiotem analizy. Powyżej zalegają osady ewaporatowe datowane na późny baden $[2,4]$. Nad poziomem anhydrytowym, który w obszarze zapadliska przedkarpackiego stanowi ważny sejsmiczny horyzont korelacyjny, leżą nierozdzielone osady badenu górnego (warstwy chodenickie/grabowieckie) oraz sarmatu (formacja z Machowa/iły krakowieckie) [1, 9].

W analizowanej części utworów miocenu autochtonicznego zostało wykazane [6, 14], że budujące go osady mają charakterystyczną geometrię. Zdefiniowano ją jako tzw. klinoform, będący produktem pionowej akrecji i frontalnej progradacji mobilnego szelfu rozwiniętego wzdłuż południowej granicy zapadliska przedkarpackiego [6]. Jego formę zinterpretowano również na podstawie regionalnych linii sejsmicznych w obszarze pomiędzy Bochnią a Pilznem [6]. Porębski [15] opisał ją bardziej szczegółowo, interpretując wewnętrzną architekturę, co dało podstawę do zdefiniowania jej jako delty krawędzi szelfu. Tego typu delta jest najczęściej efektem spadku względnego poziomu morza oraz progradacji facji osadowych w kierunku centrum basenu [16], co w tym przypadku zostało zinterpretowane w ten sposób przez wspomnianego autora.
Na rozwój tej części zapadliska przedkarpackiego wpływ miały Karpaty oraz jednostka zgłobicka (nieinterpretowane w tej pracy). W części poza strefą deformacji tektonicznych istotną rolę odgrywały uskoki, zarówno te starsze przedmioceńskie, jak i reaktywowane w czasie sedymentacji utworów mioceńskich, które niewątpliwie wiążą się z etapami subsydencji tektonicznej. Przypadały one w co najmniej dwóch okresach: późny karpat-wczesny baden (16 Ma) i późny baden (13-12 Ma) [11-13]. Jak wynika z przestrzennej analizy danych, ten drugi okres ma najistotniejsze znaczenie w obszarze badań. Subsydencja ta jest odpowiedzialna za ukształtowanie się znacznych deniwelacji w basenie i być może za jego pogłębianie do głębokości batialnych w części osiowej - i tym samym umożliwiła powstanie dużej wysokokątowej formy akumulacyjnej o charakterze klinoformu.

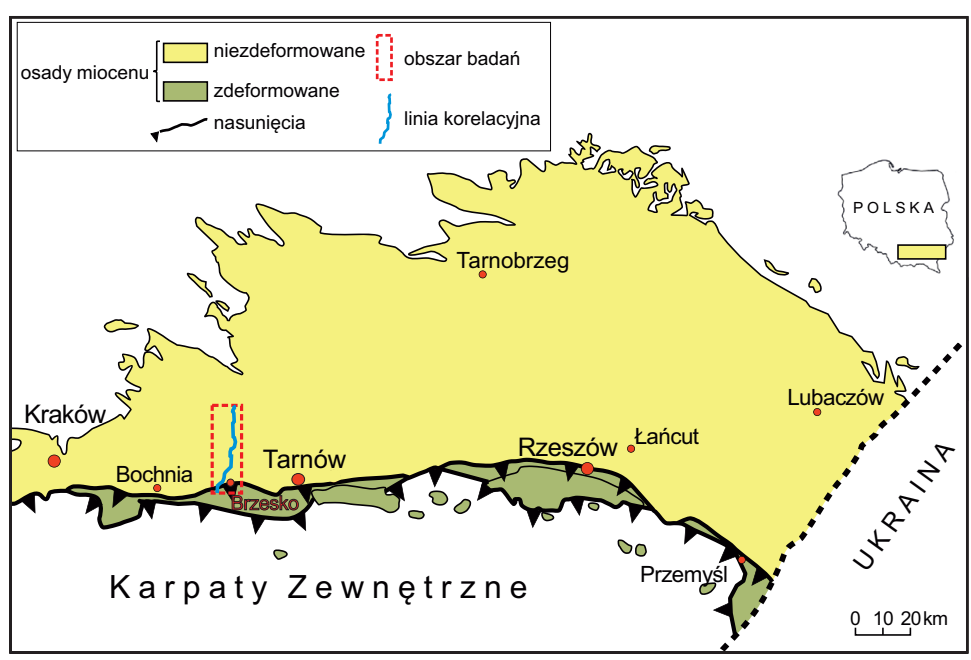

Rys. 1. Mapa lokalizacji obszaru badań wraz z zaznaczonym przebiegiem linii korelacyjnej na tle obszaru zapadliska przedkarpackiego (zmodyfikowany [17])

\section{Wykorzystane materiały}

Do realizacji pracy wykorzystano materiały geofizyczne (głębokościowa sejsmika 2D i 3D, geofizyka otworowa) oraz dokumentacje wynikowe wybranych otworów. Dane te pozwoliły na konstrukcję regionalnej sejsmicznej linii korelacyjnej o przebiegu S-N (rysunki 1, 2a).
Linia ta została zinterpretowana na podstawie metodyki łączącej stratygrafię sekwencji i sejsmostratygrafię (opis poniżej). W tym celu posłużono się krzywymi geofizycznymi, głównie profilowaniami gamma (GR) i potencjałów naturalnych (SP). Krzywe nie były normalizowane, służyły jedy- 
nie do oceny jakościowej i analizy zmiany trendu uziarnienia oraz stanowiły wsparcie w procesie wyznaczenia głównych granic korelacyjnych (SB, MFS).

Skorzystano też z dostępnych danych stratygraficznych opartych o datowanie za pomocą otwornic (brak datowań nanoplanktonem wapiennym), jednak ze względu na zbyt słabą rozdzielczość nie stanowiły one istotnego wsparcia w in- terpretacji. Z racji wieku wykonywanych wierceń i szczątkowego rdzeniowania profilu mioceńskiego dane te ograniczają się do określenia wieku analizowanych utworów w zakresie bardzo ogólnym: górny baden/sarmat $(\mathrm{Mb} 2 / \mathrm{Mb} 3)$ oraz wieku podłoża miocenu. W obszarze badań nie ma wyznaczonej granicy baden-sarmat. Całość danych zintegrowano w oprogramowaniu Schlumberger Petrel.

\section{Zastosowany proces analizy danych}

W niniejszej pracy zastosowano metodykę interpretacji opartą na stratygrafii sekwencji $[10,19,21]$ oraz sejsmostratygrafii $[18,20]$. Integracja tych dwóch metod dała możliwość interpretacji utworów miocenu autochtonicznego w czasie, jednak uzyskany wynik jest obarczony wysoką niepewnością z powodu ograniczonej ilości danych. Brak informacji geologicznej w postaci rdzeni, a co za tym idzie - profili sedymentologicznych oraz datowań mikropaleontologicznych, uniemożliwiał przeprowadzenie klasycznej interpretacji stratygraficznej. Również dane sejsmiczne w domenie głębokości nie pozwalały na dowiązanie informacji otworowych (poprzez tworzenie sejsmogramów syntetycznych). Poprawne położenie wykorzystanych otworów względem sejmiki było weryfikowane na podstawie dopasowania piku stratygraficznego Mb2 do wyraźnego na wszystkich materiałach sejsmicznych reflektora, związanego ze stropem ewaporatów.

Interpretację sprowadzono zatem do wyznaczenia granic sekwencji (SB) i granic o charakterze maksimum zalewu (MFS). Podobnie wygląda sytuacja z rozdzieleniem utworów badenu od utworów sarmatu. W zasadzie brak jest informacji na ten temat, ponieważ z interpretacji materiału mikropaleontologicznego zawartego w sprawozdaniach otworowych nie można wnioskować o tej granicy w sposób bezpośredni, a opisywane zespoły otwornicowe wskazują na dużą redepozycję.

Przyjęto założenie, że profilowania geofizyczne (głównie profilowania gamma i potencjałów naturalnych) dobrze odpowiadają litologii, a charakter ich zapisu możliwy jest do korelowania między sąsiednimi otworami oraz na linii regio- nalnej. Wobec tego granice interpretowane na sekcjach sejsmicznych, nazywane granicami sekwencji (SB), wyznaczano w spągu nagłego spadku wartości profilowania GR i SP. Są one interpretowane jako odzwierciedlenie możliwych granic erozyjnych, ponad którymi występujące grubsze ziarno wskazuje na wyraźny kontrast facjalny. Powierzchnie maksymalnego zalewu (MFS) wyznaczano w miejscu o najwyższym stopniu zailenia na krzywych geofizyki otworowej.

Takie założenia dały możliwość do wyinterpretowania SB i MFS. Należy zauważyć, że w większości wykorzystanych danych profilowania gamma były w jednostkach pseudo-API. Ich prezentacja na przekroju sejsmicznym służy jedynie do zobrazowania trendu zapiaszczenia. Profilowania zostały wyświetlone w skali normalnej (z lewej strony) i odwróconej (z prawej strony).

Dodatkowo w interpretacji posłużono się założeniem, że granice sekwencji w obrazie sejsmicznym prowadzone będą po fazie dodatniej (czerwonej), natomiast powierzchnie maksimum zalewu po fazie ujemnej (niebieskiej). Wynika to z teoretycznych wartości współczynników odbicia. $\mathrm{Na}$ granicy przejścia $\mathrm{z}$ drobnoziarnistej frakcji na grubszą współczynniki odbicia będą miały wartość dodatnią (SB). Granica MFS, charakteryzująca się osadami o najdrobniejszej frakcji, pokrywanymi osadami związanymi ze spłycaniem zbiornika (dostawa grubszego materiału), powinna posiadać ujemne współczynniki odbicia. Założenia te pozwoliły na spójną korelację refleksów sejsmicznych na wszystkich materiałach sejsmicznych na podstawie danych geofizyki otworowej.

\section{Wyniki interpretacji}

W obszarze zdjęcia 3D, będącego głównym obiektem analizy, wyinterpretowano szereg granic, którym przypisano rangę granic sekwencji (SB) lub powierzchni maksimum zalewu (MFS). Następnie wybrano najbardziej charakterystyczną intersekcję i dowiązano ją do pozostałych materiałów sejsmicznych, którymi dysponowano. W ten sposób został wykonany jeden przekrój korelacyjny w skali regionalnej (rysunek 2) o przebiegu S-N, którego całkowita długość wynosi 24,5 km (w linii prostej $20 \mathrm{~km}$ ). W jego obrębie wyinterpretowano 11 granic o randze SB i 9 MFS. Interpretacja ta została również przedstawiona na krótszych liniach o przebiegu NW-SE (rysunek 3a) oraz W-E (rysunek 3b), w celu pokazania, że wyznaczone granice można śledzić w obszarze większym niż zasięg linii korelacyjnej.

Punktem wyjścia do interpretacji była północna część linii korelacyjnej, pokazana na rysunkach 2a i 2 b. Widać na 

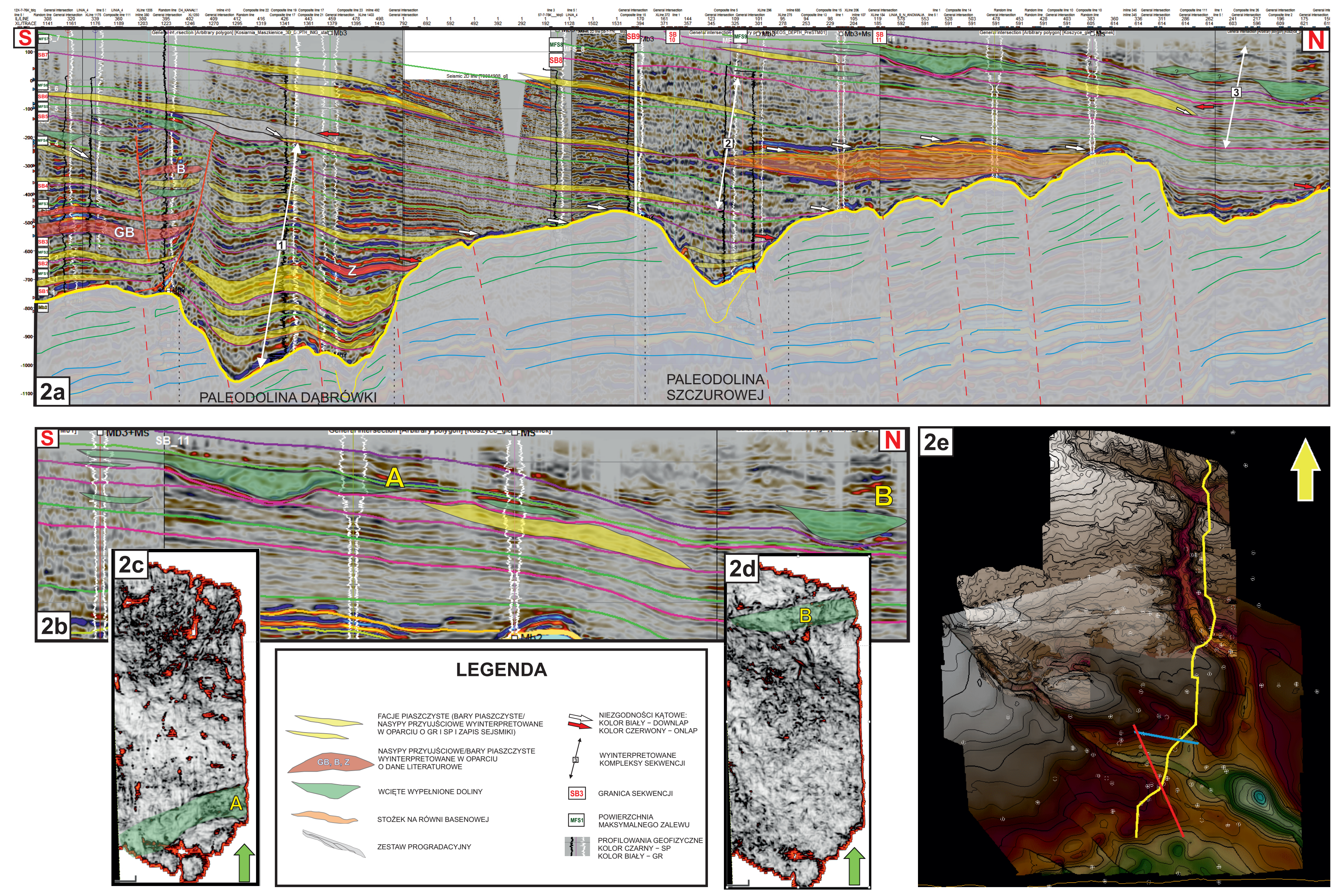

Rys. 2a. Zinterpretowana korelacyjna linia sejsmiczna, której przebieg zaznaczony jest na rys. 2e. Granice sekwencji SB oznaczone są kolorem fioletowym, a granice powierzchni maksymalnego zalewu kolorem zielonym. 2b - powiększony fragment północnej czę́ci korelacyjnej linii sejsmicznej z dobrze widocznymi erozyjnymi korytami A i B. 2c - głębokościowe cięcie sejsmiczne z widocznym przebiegiem koryta A. 2d - głębokościowe cięcie sejsmiczne z widocznym przebiegiem koryta B. $2 \mathrm{e}$ - mapka przebiegu korelacyjnej linii sejsmicznej (kolor żółty) na tle morfologii podłoża miocenu 
niej wyraźnie zarysowujące się w zapisie sejsmicznym formy zinterpretowane jako wcięcia erozyjne. Ich przebieg względem siebie jest równoległy, o generalnej rozciągłości WSW-NEN, co dobrze widać na poziomym cięciu sejsmicznym (rysunki 2c, 2d). Zostały one zinterpretowane jako doliny, związane z erozyjnym rozcięciem płytkiej strefy szelfu, najprawdopodobniej w trakcie niskiego stanu względnego poziomu morza (WPM). Granicom, które wyznaczają przestrzennie to erozyjne rozcięcie, przypisano rangę granic sekwencji SB10 oraz SB11 (numeracja wynika z kolejności wyinterpretowanych granic od najstarszej do najmłodszej). Szczególnie interesująca jest forma związana z SB10, której szerokość wynosi blisko 1900 m, a dwudzielny charakter wskazuje na jej wieloetapową genezę (rozcinanie/wypełnianie). Odległość dzieląca te formy od obecnej granicy nasunięcia karpackiego wynosi w przybliżeniu około 20 kilometrów. Założono zatem, że jeśli są one związane z granicami sekwencji i są dobrze widoczne w płytszej części utworów miocenu, powinny występować również w głębszej części analizowanego profilu, konsekwentnie w kierunku Karpat. Założenie to jest istotne ze złożowego punktu widzenia, szczególnie w kontekście zrozumienia rozkładu potencjalnych kolektorów piaskowcowych. Mogą one być związane zarówno z izolowanymi dolinami (jak w tym przypadku), jak i z nasypami przyujściowymi - interpretowanymi wcześniej w tym obszarze i opisywanymi w materiałach niepublikowanych (dokumentacje otworowe).

Charakterystyczną cechą zapisu amplitudowego w sukcesji nadewaporatowej $\mathrm{w}$ analizowanym obszarze jest forma zinterpretowana jako klinoform. Wyklinowuje się ona ku północny (średni kąt upadu $1^{\circ}$ ), do poziomu ewaporatowego, tworząc szereg niezgodności zstępujących (ang. downlap) i wstępujących (ang. onlap). Jakość zapisu sejsmicznego w tym obszarze dobrze przedstawia tę formę i umożliwia ciągłą interpretację wyznaczonych granic. Wyjątkiem jest południowa (przykarpacka) część analizowanego obszaru, będąca czołową częścią tzw. jednostki zgłobickiej, ciągnącej się aż po nasunięcie karpackie. Charakteryzuje się ona złożonością geometrii ośrodka i prawdopodobnie wynika z nałożenia się procesów tektonicznych na procesy sedymentacyjne. Utwory mioceńskie w tej strefie są mocno zdeformowane, co oprócz sejsmiki potwierdzają dane otworowe.

Z punktu widzenia przeprowadzonej interpretacji, na regionalnej linii korelacyjnej, jak i na zdjęciu 3D, w profilu utworów miocenu występuje wyraźna trójdzielność (dalej nazywana kompleksem pierwszym, drugim i trzecim). Charakteryzuje się ona koncentracją lub znacznym rozejściem wyinterpretowanych granic. Pierwszy kompleks wyznaczony jest od stropu Mb2 do SB6, drugi od SB6 do SB8, trzeci od SB8 do SB11. Sekwencje są opisywane w kolej- ności od spągu, a ich nazewnictwo opiera się na kolejnych granicach sekwencji. I tak np. sekwencję pierwszą wyznacza w spagu SB1, a w stropie SB2, i tak kolejno do stropu utworów miocenu.

Pierwsze dwie sekwencje (w kompleksie pierwszym) są interpretowane wyłącznie w południowej części linii korelacyjnej. Ich łączna miąższość waha się od około $150 \mathrm{~m}$ w strefie wyruszonej do ponad $300 \mathrm{~m}$ w obrębie paleodoliny Dąbrówki. W sekwencjach 1 i 2 (pomiędzy SB1 a SB3) zinterpretowano głównie ciągi depozycyjne niskiego stanu WPM. W ich obrębie - opierając się na danych otworowych - występują, zwłaszcza w erozyjnym obniżeniu podłoża (paleodolinie Dąbrówki) miąższe pakiety utworów piaszczystych (rysunki 2a, 3a). Są one obecne nie tylko na granicach SB1 i SB2, ale też powyżej granicy MFS1. Znaczne ich nagromadzenie (interpretowanych tutaj jako serie piaskowcowe) w tej części profilu może też być związane z osiowym transportem wzdłuż paleodoliny lub z naturalną paleoformą predysponującą do akumulacji facji piaszczystych w czasie zarówno niskiego, jak i transgresywnego czy nawet wysokiego stanu WPM.

Sekwencja trzecia (pomiędzy SB3 a SB4), o średniej miąższości około $150 \mathrm{~m}$ (por. pomiędzy IL308 a 498) (rysunek 2a, 3a), podobnie jak dwie wcześniejsze, zdominowana jest ciągiem depozycyjnym niskiego stanu WPM. Wyżejległe, wyinterpretowane ciągi: transgresywny i wysokiego stanu WPM są znacznie mniejszej miąższości, co może wynikać z ich późniejszego erozyjnego usunięcia przez SB4. Sekwencja trzecia (od granicy SB3) rozpoczyna się miąższymi pakietami (około $50 \mathrm{~m}$ ) piaskowców (por. IL308-339 na rysunku 2a). Piaskowce te stwierdzone zostały w obrębie struktury GB. W opracowaniach otworowych zinterpretowane są jako utwory o charakterze wału przybrzeżnego, z dobrymi właściwościami kolektorowymi, o rozciągłości W-E.

W północnej części sekwencji trzeciej granica SB3 wyklinowuje się do krawędzi paleodoliny poprzez niezgodność typu onlap. Wykazane tam nagromadzenia piaskowców wynikać mogą z faktu, że powstały np. w ciągu niskiego stanu WPM, rozwijając się ponad tą granicą. Ich obecność została potwierdzona na strukturze Z (rysunki 2a, 3a, 3b). Podobnie jak w rejonie GB piaskowce te w ujęciu przestrzennym posiadają wydłużoną formę, zinterpretowaną jako wał przybrzeżny (materiały niepublikowane - dokumentacje wynikowe otworów w obszarze badań). Taka interpretacja wynikać może również z analizy zapisu sejsmicznego oraz geofizyki otworowej.

Sekwencja czwarta (pomiędzy SB4 a SB5) ma średnią miąższość około $200 \mathrm{~m}$ i ponownie dominują w niej utwory zinterpretowane jako powstałe $\mathrm{w}$ ciągu systemowym niskiego stanu WMP. Na postawie zapisu krzywych geofizycznych GR i SP można interpretować niewielkiej miąższości 
facje piaszczyste, związane bezpośrednio z SB4, oraz wciętą dolinę (rysunek 2a, IL395). Na głębokości około $300 \mathrm{~m}$ p.p.m. (rysunki 2a, 3a) widoczna jest anomalia amplitudowa bright spot, związana ze strukturą B, zinterpretowana podobnie jak GB i $Z$ - jako wał piaszczysty/nasyp przyujściowy, o orientacji W-E. Struktura B ograniczona jest w stropie granicą MFS4.

Sekwencja piąta (pomiędzy SB5 a SB6), o średniej miąższości $100 \mathrm{~m}$, przewyższa zasięgiem niżejległe sekwencje. Sięga ona aż po paleodolinę Szczurowej (rysunek 2a, IL94). W obrębie tej sekwencji zapis sejsmiczny oraz niewielka ilość danych otworowych nie pozwoliły na wyinterpretowanie szczególnie istotnych dla tej pracy ciał piaszczystych, nie licząc dwóch małych wciętych dolin (IL395), wyinterpretowanych wyłącznie na podstawie zapisu danych geofizyki wiertniczej.

W sekwencji szóstej (pomiędzy granicami SB6 i SB7) w południowej części analizowanego obszaru (IL402-459) zapis refleksów wskazuje na małoskalowy zestaw progra- dacyjny (zaznaczony kolorem szarym) (rysunek 2a), występujący powyżej granicy SB6. Jego rozwój można wiązać ze stopniowym wzrostem WPM w warunkach ciągu transgresywnego. W obrębie tej formy na krzywych GR i SP nie zapisuje się wyraźny wzrost zapiaszczenia tak jak w części basenowej związanej bezpośrednio z granicą sekwencji SB6 (rysunek 2a, XL1531). Zestaw ten może być zatem związany z redepozycją materiału drobnoziarnistego podczas stopniowego wzrostu WPM. Powyżej została wyinterpretowana MFS6, która stanowi stropową powierzchnię ciągu transgresywnego w stropie przykrytą przez granicę SB7.

Z sekwencją siódmą (pomiędzy SB7 i SB8) związany jest wysunięty na północ element wyinterpretowany jako stożek na równi basenowej (na granicy łączenia dwóch zdjęć sejsmicznych 3D XL325-185 i XL592-605). Jego długość na przekroju wynosi ponad $6000 \mathrm{~m}$ i jest on ograniczony od północy przez strukturalne wyniesienie mioceńskiego podłoża, do którego się wyklinowuje. Charakterystycznym elementem tej złożonej formy akumulacyjnej jest dochodzenie
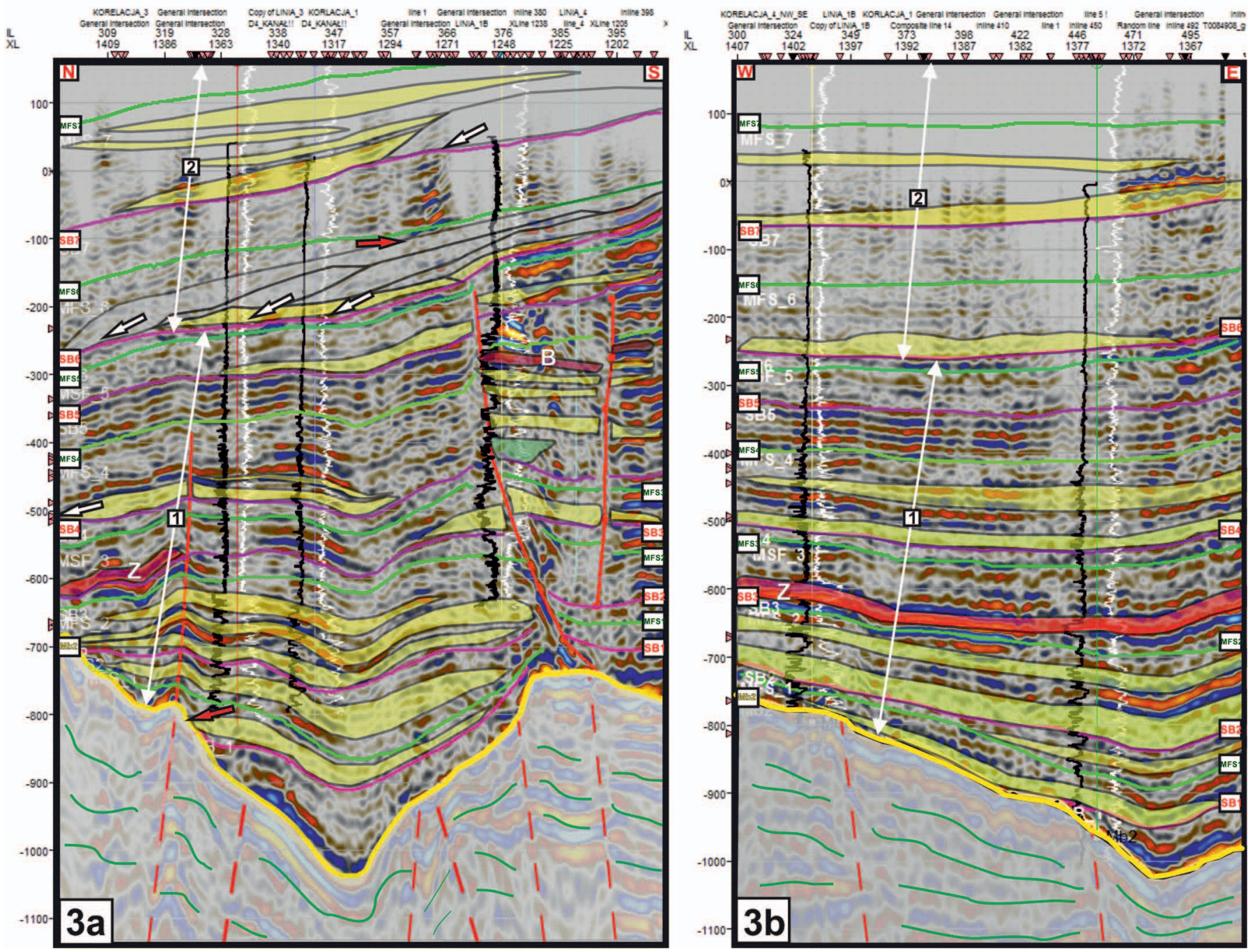

Rys. 3a. Zinterpretowana linia sejsmiczna o przebiegu N-S. Lokalizacja na rys. 2e: linia czerwona. 3b - zinterpretowana linia sejsmiczna o przebiegu W-E. Lokalizacja na rys. 2e: linia niebieska 
refleksów sejsmicznych do jej stropowych części, w postaci wyklinowań zstępujących downlap. Można to interpretować stopniowym podnoszeniem się poziomu morza i rozwojem ciągu transgresywnego ponad nim.

Miąższość tej sekwencji w rejonie stożka wynosi blisko 300 m, co może świadczyć o wysokiej subsydencji w późnym badenie, opisywanej przez Oszczypkę [11]. Założono więc, że sekwencja siódma może reprezentować utwory powstałe w późnym badenie/wczesnym sarmacie, chociaż nie jest to potwierdzone jednoznacznie badaniami biostratygraficznymi.

Powyżej granicy SB8 obserwuje się zjawisko zmniejszenia miąższości kolejnych sekwencji. Może to być wynikiem wieloetapowej sedymentacji w warunkach zdominowanych sedymentacją w ciągach depozycyjnych niskiego stanu WPM, przy relatywnie wysokim tempie subsydencji.

W sekwencji dziewiątej (pomiędzy SB9 i SB10), której miąższość wynosi około $50 \mathrm{~m}$, na podstawie zapisu GR (w otworze na IL383) wyinterpretowano fację piaszczystą. Od północy widoczne jest dość wyraźne dochodzenie do niej refleksów (typu onlap), związane prawdopodobnie z rozwojem ciągu transgresywnego, który nie kończy się granicą MFS, lecz SB10. Takie następstwo może być wynikiem procesów erozyjnych związanych z obniżeniem WPM (SB10).

W sekwencji dziesiątej (pomiędzy SB10 a SB11) znajduje się wcięta dolina erozyjna, opisana na początku rozdziału, stanowiąca, jak to wspomniano na wstępie, punkt wyjścia do interpretacji pełnej sukcesji utworów miocenu autochtonicznego w rejonie Brzeska.

Granica SB11 jest ostatnią, jaką wyznaczono, ze względu na brak możliwości śledzenia refleksów w górnej, północnej części linii korelacyjnej oraz brak korelacji z danymi otworowymi i profilowaniami geofizyki wiertniczej. Wyjątek stanowią wyinterpretowane na sejsmice wcięte doliny opisane wyżej.

\section{Wnioski końcowe}

Przeprowadzona próba interpretacji materiałów sejsmicznych, oparta na założeniach metodyki identyfikacji sekwencji depozycyjnych z wykorzystaniem pomiarów geofizyki otworowej oraz na ich wzajemnym dowiązaniu, pozwoliła na zidentyfikowanie 11 granic sekwencji i 9 powierzchni maksimum zalewu. W obrębie tych sekwencji w zapisie sejsmicznym, geofizyki otworowej i na podstawie danych literaturowych zinterpretowano facje piaszczyste, deponowane głównie w trakcie niskiego stanu WMP, związane z nasypami przyujściowymi/barami piaszczystymi oraz wciętymi dolinami w szelfie. Tego typu interpretacja, przeprowadzona na ograniczonej ilości danych w ograniczonym obszarze, pozwala tylko na lokalne zrozumienie dystrybucji skał zbiornikowych w tej części zapadliska przedkarpackiego.

W opracowywanym obszarze wpływ na geometrię osadów mioceńskich ma tektonika związana z nasuwającymi się Karpatami, obecność u ich czoła tzw. jednostki zgłobickiej oraz morfologia podłoża. Zapis sejsmiczny w strefie przykarpackiej jest zniekształcony przez procesy tektoniczne, co uniemożliwiało wyznaczenie i prześledzenie granic SB i MFS od samego czoła Karpat. Słabymi punktami zastosowanej metodyki w analizowanym obszarze były:

- brak materiału rdzeniowego pozwalającego na przeprowadzenie analiz sedymentologicznych oraz datowania mikropaleontologicznego,

- brak możliwości dowiązania krzywych geofizyki otworowej (GR i SP) do sejsmiki z powodu nieposiadania przez autora czasowych wersji materiałów sejsmicznych,

- dane sejsmiczne wykonane w różnych przedziałach lat, różniące się skalą rozdzielczości pionowej.
Zinterpretowana linia korelacyjna, charakteryzująca się trójdzielnym podziałem rozmieszczenia sekwencji, obrazuje, w jaki sposób następowało przemieszczanie się aktywnej części czoła delty wraz z facjami piaskowcowymi (elementami architektury depozycyjnej tej delty) oraz sedymentacją przybrzeżną, co było kontrolowane procesem nasuwania się Karpat na swoje przedpole.

W pierwszym kompleksie zostało wyróżnionych 5 sekwencji (pomiędzy SB1 a SB6). Charakteryzują się one przewagą traktów niskiego stanu WMP. Wyinterpretowano w ich obrębie liczne facje piaszczyste. Najistotniejszymi są te zarówno udokumentowane, jak i potwierdzone w niniejszej pracy w rejonie struktur GB (południowa) i Z (północna) w obrębie sekwencji trzeciej (pomiędzy SB3 a SB4) oraz struktura B w sekwencji czwartej. Zostały one zinterpretowane jako rozciągłe przybrzeżne bary. Rozmieszczenie tych piaszczystych form o generalnej rozciągłości W-E i ich stopniowe przemieszczanie się w kierunku północnym może potwierdzać założenie o północnej trajektorii szelfu związanej z progradacją Karpat (podobnie jak we wschodniej części zapadliska przedkarpackiego [3]).

Drugi kompleks obejmuje dwie sekwencje (pomiędzy SB6 a SB8). Wyniki interpretacji pokazują, że zdominowany jest on traktami transgresywnym i wysokiego stanu WMP. Charakteryzuje się on dużymi miąższościami pomiędzy poszczególnymi granicami sekwencji i brakiem tak charakterystycznych form piaskowcowych jak w kompleksie pierwszym. Miąższość sekwencji siódmej wynosi blisko $300 \mathrm{~m}$, co może świadczyć o wysokiej subsydencji tektonicznej. Założono więc, na podstawie danych literaturowych [12], 
że sekwencja siódma może reprezentować utwory powstałe na przełomie późnego badenu-wczesnego sarmatu, chociaż nie jest to potwierdzone jednoznacznie badaniami biostratygraficznymi.

Trzeci kompleks (pomiędzy SB8 a SB11), podobnie jak pierwszy, cechuje się przewagą traktów niskiego stanu WMP, a odległości pomiędzy poszczególnymi granicami SB wyno- szą średnio $100 \mathrm{~m}$. W sekwencjach wyinterpretowano, głównie na podstawie zapisu amplitudowego, formy erozyjne zinterpretowane jako doliny, związane z erozyjnym rozcięciem płytkich stref szelfu w trakcie niskiego WPM. Przebieg omawianych dolin, w przeciwieństwie do tych z kompleksu pierwszego (wyinterpretowanych na podstawie zapisu profilowań geofizyki otworowej), można prześledzić na sejsmice.

Autor dziękuje PGNiG SA za udostęnienie danych sejsmicznych, danych geofizyki wiertniczej oraz dokumentacji wynikowych otworów z rejonu badań.

Prosimy cytować jako: Nafta-Gaz 2017, nr 12, s. 928-934, DOI: 10.18668/NG.2017.12.03

Artykuł nadesłano do Redakcji 29.12.2016 r. Zatwierdzono do druku 1.08.2017 r.

Artykuł powstał na podstawie pracy statutowej pt.: Analiza utworów miocenu autochtonicznego brzeżnej części zapadliska przedkarpackiego na wschód od Bochni - praca INiG - PIB na zlecenie MNiSW; nr zlecenia: 15/SG, nr archiwalny: DK-4100-15/2016.

\section{Literatura}

[1] Alexandrowicz S.W., Garlicki A., Rutkowski J.: Podstawowe jednostki litostratygraficzne miocenu zapadliska przedkarpackiego. Kwartalnik Geologiczny 1982, vol. 26, s. 470-471.

[2] Andreyeva-Grigorovich A.S., Oszczypko N., Savitskaya N.A., Ślączka A., Trofimovich N.A.: Correlation of Late Badenian salts of the Wieliczka, Bochnia and Kalush areas (Polish and Ukrainian Carpathian Foredeep). Ann. Soc. Geol. Pol. 2003, vol. 73, nr 2, s. 67-89.

[3] Dziadzio P., Liszka B., Maksym A., Staryszak G.: Środowisko sedymentacji utworów miocenu autochtonicznego w brzeżnej strefie Karpat, a interpretacja geologiczno-złożowa w obszarze Husów-Albigowa-Krasne. Nafta-Gaz 1997, nr 9, s. 407-414.

[4] Dziadzio P., Maksym A., Olszewska B.: Sedymentacja utworów miocenu we wschodniej części zapadliska przedkarpackiego. Przegląd Geologiczny 2006, vol. 54, nr 5, s. 413-420.

[5] Jędrzejowska-Zwinczak H., Połtowicz S.: Zastosowanie sejsmostratygrafii w analizie paleogeologicznej. Nafta-Gaz 1994, nr 10, s. 419-437.

[6] Krzywiec P.: Contrasting tectonic and sedimentary history of the central and eastern parts of the Polish Carpathian foredeep basin - results of seismic data interpretation. Marine and Petroleum Geology 2001, vol. 18, nr 1, s. 13-38.

[7] Krzywiec P.: Sedymentacja, tektonika i geodynamika centralnej części zapadliska przedkarpackiego - wnioski z interpretacji danych sejsmicznych. Problemy interpretacyjne sejsmiki. Czesść 2. I Krajowa Konferencja Naukowo-Techniczna, Mogilany 1994, s. 157-171.

[8] Krzywiec P.: Tektonika klinowa i strefy trójkątne-zarys problematyki. Przegląd Geologiczny 2004, vol. 52, nr 10, s. 985-989.

[9] Łomnicki M.: Ity krakowieckie. Kosmos 1897, vol. 22, s. 571578.

[10] Mitchum R.M., Sangree J.B., Vail P.R., Wornardt W.W.: Recognizing sequences and systems tracts from well logs, seismic data, and biostratigraphy: examples from Late Cenozoic of the Gulf of Mexico. [W:] Weimer P., Posamentier H. (eds.): Siliciclastic sequence stratigraphy. Recent developments and applications. AAPG Memoir 1993, vol. 58, s. 163-197.

[11] Oszczypko N.: Powstanie i rozwój polskiej czéści zapadliska przedkarpackiego. Przegląd Geologiczny 2006, vol. 54, nr 5, s. 396-403.

[12] Oszczypko N.: Przebieg mioceńskiej subsydencji w polskiej części zapadliska przedkarpackiego. Prace Państwowego Instytutu Geologicznego 1999, vol. 168, s. 209-230.
[13] Oszczypko N.: The Western Carpathian foredeep - development of the foreland basin in front of the accretionary wedge and its burial history (Poland). Geologica Carpathica 1998, vol. 49, nr 6, s. 1-18.

[14] Porębski S.J.: Środowisko depozycyjne sukcesji nadewaporatowej (górny baden) w rejonie Kraków - Brzesko (zapadlisko przedkarpackie). Prace Państwowego Instytutu Geologicznego 1999, vol. 168, s. 97-118.

[15] Porębski S.J., Pietsch K., Hodiak R., Steel R.J.: Origin and sequential development of Badenian-Sarmatian clinoforms in the Carpathian Foreland Basin (SE Poland). Geologica Carpathica 2003, vol. 54, nr 2, s. 119-136.

[16] Porębski S.J., Steel R.J.: Shelf-margin deltas: their stratigraphic significance and relation to deepwater sands. Earth-Science Reviews 2003, vol. 62, nr 3-4, s. 283-326.

[17] Porębski S.J., Warchoł M.: Znaczenie przeplywów hiperpyknalnych i klinoform deltowych dla interpretacji sedymentologicznych formacji z Machowa (miocen zapadliska przedkarpackiego). Przegląd Geologiczny 2006, vol. 54, nr 5, s. 421-429.

[18] Sheriff R.E.: Seismic Stratigraphy. Springer; Softcover reprint of the original $1^{\text {st }}$ ed. 1980 edition.

[19] Vail P.R.: Seismic stratigraphy interpretation using sequence stratigraphy. Part I: Seismic stratigraphy interpretation procedure. [W:] Bally A.W. (ed.): Atlas of Seismic Stratigraphy. Am. Assoc. Petrol. Geol. Stud. Geol. 1987, vol. 27, nr 1, s. 1-10.

[20] Vail P.R., Mitchum Jr. R.M., Thompson S.: Seismic stratigraphy and global changes of sea level. Part 3: Relative changes of sea level from coastal onlap. [W:] Payton Ch.E., (ed.): Seismic stratigraphy - applications to hydrocarbon exploration. AAPG Memoir 1977, vol. 26, s. 63-97.

[21] Van Wagoner J.C., Mitchum R.M., Campion K.M., Rahmanian V.D.: Siliciclastic sequence stratigraphy in well logs, cores, and outcrops: concepts for high resolution correlation of time and facies. AAPG Methods in Exploration Series 1990, nr 7, s. 1-55.

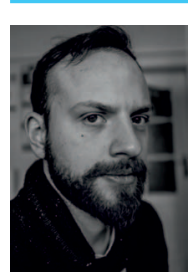

Mgr inż. Arkadiusz DROZD

Specjalista inżynieryjno-techniczny w Zakładzie Geologii i Geochemii.

Instytut Nafty i Gazu - Państwowy Instytut Badawczy ul. Lubicz 25 A

31-503 Kraków

E-mail: arkadiusz.drozd@inig.pl 